Meyerhof, O. (1945). J. biol. Chem. 157, 105.

Meyerhof, O. \& Kaplan, A. (1951). Arch. Biochem. Biophys. 33, 282.

Meyerhof, O. \& Oesper, P. (1947). J. biol. Chem. 170, 1.

Meyerhof, O. \& Wilson, J. R. (1949). J. biol. Chem. 180, 575.

Nelson, N. (1944). J. biol. Chem. 153, 373.

Nilsson, R. \& Alm, F. (1941). Biochem. Z. 308, 262.

Prankerd, T. A. J. \& Altman, K. I. (1954). Biochem. J. 58, 622.

Roe, J. H., Epstein, J. H. \& Goldstein, N. P. (1949). J. biol. Chem. 178, 839.

Rothstein, A. (1954a). The Enzymology of the Cell Surface; Protoplasmatologia, 2, E, 4. Vienna: Springer-Verlag.

Rothstein, A. (1954b). Symp. Soc. exp. Biol., p. 165.

Rothstein, A. (1955). In Electrolytes in Biological Systems. Ed. by Shanes, A. Washington, D.C.: American Physiological Society.

Rothstein, A. \& Demis, C. (1953). Arch. Biochem. Biophys. 44, 18.

Rothstein, A. \& Meier, R. (1949). J. cell. comp. Physiol. 34, 97.
Schriner, R. L. \& Fuson, R. C. (1940). Systematic Identification of Organic Compounds, p. 137. New York: John Wiley and Sons Inc.

Scott, T. A. \& Melvin, E. H. (1953). Analyt. Chem. 25, 1656.

Shaw, W. N. \& Stadie, W. C. (1957). J. biol. Chem. 227, 115.

Spiegelman, S. \& Nozawa, M. (1945). Arch. Biochem. 6, 303.

Spiegelman, S., Reiner, J. M. \& Cohnberg, R. (1947). J. gen. Physiol. 31, 27.

Stier, T. J. B. \& Stannard, J. N. (1936). J. gen. Physiol. 19, 479.

Umbreit, W. W., Burris, R. H. \& Stauffer, J. G. (1949). Manometric Methods and Tissue Metabolism. Minneapolis: Burgess Publishing Co.

Wade, H. E. \& Morgan, D. M. (1955). Biochem. J. 60, 264.

Wang, C. H., Gregg, C. T., Forbusch, I. A., Christenson, B. E. \& Cheldelin, V. H. (1956). J. Amer. chem. Soc. 78, 1869.

Westerfield, W. W., Stotz, E. \& Berg, R. L. (1942). J. biol. Chem. 144, 657.

\title{
Respiratory Enzyme Studies in Tetrahymena pyriformis
}

\section{STABILIZATION OF ELECTRON-TRANSPORT COMPONENTS*}

\author{
BY H. J. EICHEL \\ Department of Biological Chemistry, Hahnemann Medical College, Philadelphia, Pa., U.S.A.
}

(Received 28 February 1958)

Early attempts to demonstrate an active succinoxidase system in cell-free homogenates of the ciliated protozoan Tetrahymena pyriformis were unsuccessful when preparations were made in a glass homogenizer or Waring Blendor with the use of sea sand, Ballotini, alumina or different grades of quartz. Such homogenates were either completely inactive or consumed very little extra oxygen in the presence of added succinate. However, the passage of whole cells through a Logeman homogenizer yielded preparations with quite active electron-transport systems as reflected by succinoxidase, succinic cytochrome $c$ reductase, reduced diphosphopyridine nucleotide oxidase, reduced diphosphopyridine nucleotide cytochrome $c$ reductase and diaphorase activities (Eichel, 1954, $1956 a, c)$. On the other hand, kinetic studies of enzymes in these homogenates are seriously handicapped by the extraordinary instability of the electron-transport systems present in the particles, and purification of the enzymes noted above is rendered exceedingly difficult. Although the marked lability of the electron-transport chains argued for seeking other methods of cell disruption

* Part 3: Eichel (1956b). which might give more stable and perhaps standardized enzyme preparations, it was felt that the reasonably high initial activities of these homogenates, and the great ease with which they could be prepared without the use of 'contaminating' grinding materials, spoke for a search for means of stabilizing them to facilitate certain types of enzymic studies. In addition, an effective stabilizing agent or group of agents might be expected to yield information about the nature of instability of the particulate electron-transport systems. In part 3 of this series (Eichel, 1956b), as part of a study of some properties of the reduced diphosphopyridine nucleotide oxidase system, it was reported that the latter was stabilized for brief periods by suspending and homogenizing whole cells in alkaline phosphate buffer. This procedure, however, resulted in a 50-60\% loss of the initial activity.

This paper deals with the use of two types of agents which have been found to be effective stabilizers of the entire electron-transport systems encompassing the span of either succinate or reduced diphosphopyridine nucleotide to oxygen, as well as of glutamic and $\beta$-hydroxybutyric dehydrogenases. One is a relatively thermostable diffusate obtained from commercial preparations of 
crude bovine albumin and from whole blood serum, proteose peptone and yeast extract; the other is a group of at least three compounds of which succinic acid is most effective and isocitric and citric acids are somewhat less so.

\section{EXPERIMENTAL}

Cultures and preparation of homogenates. Experiments were carried out with cells of the S strain of Tetrahymena pyriformis, obtained as previously described (Eichel, 1954). Homogenates were prepared by passing freshly harvested cells through a stainless-steel Logeman (C. W. Logeman Company, New York, U.S.A.) homogenizer twice at $5^{\circ}$. This is a hand-operated apparatus in which the cells are broken by being forced through a restricted orifice during the application of pressure on a piston.

Enzyme assays. In the standard succinoxidase and succinic dehydrogenase assays, oxygen consumption was determined at $30^{\circ}$ in air by the conventional Warburg manometric method. Each vessel contained in the main compartment, in a final volume of $2.8 \mathrm{ml}$., sodium succinate, $0.054 \mathrm{M} ; \mathrm{K}_{2} \mathrm{HPO}_{4}-\mathrm{KH}_{2} \mathrm{PO}_{4}$ buffer, $0.036 \mathrm{M}$, $\mathrm{pH} \mathrm{7.1} ; \mathrm{AlCl}_{3}-$ $\mathrm{CaCl}_{2}, 0.32 \mathrm{mM}$; and Tetrahymena homogenate, with or without various compounds, $0.5 \mathrm{ml}$. The centre well contained $0.2 \mathrm{ml}$. of $20 \%(\mathrm{w} / \mathrm{v}) \mathrm{KOH}$ and filter paper. $\mathrm{Al}^{3+}$ and $\mathrm{Ca}^{2+}$ ions were added because it had been shown previously that with them the activity of the succinateoxidizing system was maintained at a somewhat higher level $(+16 \%$ ) over a period of $1 \mathrm{hr}$. (Eichel, 1954). In the succinic dehydrogenase assay, each vessel contained, in addition to the above components, $2 \mathrm{mM}-\mathrm{KCN}$ and either $0.5 \mathrm{mg}$. of phenazine methosulphate or $4 \mathrm{mg}$. of methylene blue chloride. In the rat-liver succinoxidase assay, the conditions were identical except that each vessel also contained $0.5 \mathrm{mg}$. of cytochrome $c$ and $0.4 \mathrm{ml}$. of a $1: 24$ water homogenate of liver in place of the protozoan preparation. For the manometric assays of glutamic oxidase and $\beta$-hydroxybutyric oxidase, each vessel contained in the main compartment, in a final volume of $2.8 \mathrm{ml}$., either $\mathrm{L}$ glutamic acid or sodium $\beta$-hydroxybutyrate, $0.054 \mathrm{M}$; $2 \mathrm{mg}$. of oxidized diphosphopyridine nucleotide (DPN); $\mathrm{K}_{2} \mathrm{HPO}_{4}-\mathrm{KH}_{2} \mathrm{PO}_{4}$ buffer, $0.036 \mathrm{M}, \mathrm{pH} \mathrm{7.1}$; and Tetrahymena homogenate, $0.5 \mathrm{ml}$. In manometrie assays for glutamic and $\beta$-hydroxybutyric dehydrogenases, each vessel also contained $2 \mathrm{mM}-\mathrm{KCN}$ and $0.5 \mathrm{mg}$. of phenazine methosulphate. The vessels were immersed in chopped ice during the pipetting of the reaction mixtures and were usually allowed to equilibrate for $10 \mathrm{~min}$. $(5 \mathrm{~min}$. with shaking) before closing the manometers. Readings were taken after 5 and $10 \mathrm{~min}$. and at intervals of $10 \mathrm{~min}$. thereafter for $\mathbf{l ~ h r}$.

For the standard reduced diphosphopyridine nucleotide (DPNH) oxidase assay, a model DU Beckman spectrophotometer, equipped with thermospacers, was employed at a temperature of $25^{\circ}$. To each $1 \mathrm{~cm}$. cuvette, in the order given, were added the following components which, with the exception of homogenate, had been pre-incubated at $25^{\circ}$ : 0.025 or $0.05 \mathrm{ml}$. of Tetrahymena homogenate containing an average of $1.65 \mathrm{mg}$. of $\mathrm{N} / \mathrm{ml}$.; $\mathrm{K}_{2} \mathrm{HPO}_{4}-\mathrm{KH}_{2} \mathrm{PO}$

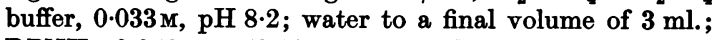
DPNH, $0.056 \mathrm{mM}(0.12 \mathrm{mg}$.). Readings $(340 \mathrm{~m} \mu)$ were taken at intervals of 15,30 or 60 sec. for at least $2-3 \mathrm{~min}$. Because of the marked loss of activity of control homo- genates with time (Eichel, 1956b) it was necessary to run frequent checks of these samples simultaneously with the treated or fortified homogenates. The DPNH cytochrome $c$ reductase assay was carried out like the DPNH oxidase test except that each cuvette also received $1 \mathrm{mg}$. of pure cytochrome $c$, and readings were taken at $15 \mathrm{sec}$. intervals for $1 \mathrm{~min}$. at $550 \mathrm{~m} \mu$. The addition of cyanide to block the reoxidation of reduced cytochrome $c$ is not required (Eichel, $1956 a$ ). Glutamic and $\beta$-hydroxybutyric dehydrogenases were also assayed spectrophotometrically by following DPN reduction at $340 \mathrm{~m} \mu$ in the presence of cyanide to block the DPNH oxidase system (Eichel, 1956a). Each cuvette contained either glutamic acid or $\beta$-hydroxybutyrate, $17 \mathrm{~mm}$; KCN, $2 \mathrm{~mm}$; $\mathrm{K}_{2} \mathrm{HPO}_{4}-\mathrm{KH}_{2} \mathrm{PO}_{4}$ buffer, $0.033 \mathrm{M}$, pH 7.1; water to $3 \mathrm{ml}$; and $1 \mathrm{mg}$. of DPN. For the glutamic dehydrogenase reaction, in which the rate decreased rapidly with time, six or seven readings were made within about $1 \mathrm{~min}$. Similar readings were taken for the $\beta$-hydroxybutyric dehydrogenase reaction, which was linear over a considerable period and more than three times as fast as the reduction of DPN by glutamate. Although both dehydrogenases were assayed at $\mathrm{pH} 7 \cdot 1$, this does not necessarily represent the optimum $\mathrm{pH}$ for these enzymes, i.e. $\beta$-hydroxybutyric dehydrogenase is more active at pH 8.2 than 7.1. Fumarase was assayed spectrophotometrically at $25^{\circ}$ by the method of Racker (1950). The substrate was $0.033 \mathrm{~m}$-malic acid and the $\mathrm{pH}$ was $7 \cdot 1$. Nitrogen determinations were carried out in duplicate by a micro$\mathrm{Kjeldahl}$ procedure.

Materials. The DPNH used in these studies was prepared enzymically by the Sigma Chemical Co., St Louis, Mo., U.S.A. The DPN and cytochrome $c$ were also products of the Sigma Chemical Co. The crude albumin preparation was obtained from the Amend Drug and Chemical Co., New York, U.S.A.

\section{RESULTS}

\section{Effect of ageing homogenates at $0^{\circ}$ on the activities of succinoxidase and succinic dehydrogenase}

The succinoxidase data presented in Table 1 were typical of very many assays made with homogenates prepared from cultures of varying ages. Since oxygen uptake was linear for only 10-20 $\mathrm{min}$. and fell off rapidly thereafter, the first $10 \mathrm{~min}$. reading was taken as the most reliable index of activity. The $60 \mathrm{~min}$. readings are given also to indicate the decline in rate. When homogenates were stored at $0^{\circ}$, they lost $30-60 \%$ of the original activity in $1 \mathrm{hr}$. By $5 \mathrm{hr}$. $75-90 \%$ of the activity disappeared and after a day all activity was gone. However, when succinic dehydrogenase was measured with either methylene blue or phenazine methosulphate as the electron acceptor, there was only slight inactivation after $5 \mathrm{hr}$. After $24 \mathrm{hr}$. the two dye systems responded somewhat differently; $60-90 \%$ of the activity towards methylene blue was lost but only 50-60\% of that towards phenazine methosulphate disappeared. The greater stability of the phenazine system as compared with the methylene-blue system is a second indication that the methylene-blue system includes at least one 
Table 1. Effect of ageing Tetrahymena pyriformis homogenates at $0^{\circ}$ on succinoxidase and succinic dehydrogenase activities

Enzyme activities were measured by the standard assays described in the Experimental section. Oxygen uptake values are given for the first $10 \mathrm{~min}$. after closing the manometers and for the first hour. The homogenate added to each vessel contained $1.04 \mathrm{mg}$. of N. SO, Succinoxidase; SDH, succinic dehydrogenase.

\begin{tabular}{cll}
$\begin{array}{c}\text { Age } \\
\text { (hr.) }\end{array}$ & $\begin{array}{c}\text { Enzyme } \\
\text { system }\end{array}$ & \multicolumn{1}{c}{ Electron acceptor } \\
0 & SO & $\mathrm{O}_{2}$ \\
& SDH & Methylene blue \\
& SDH & Phenazine methosulphate \\
1 & SO & $\mathrm{O}_{2}$ \\
& SDH & Methylene blue \\
3 & SO & $\mathrm{O}_{2}$ \\
& SDH & Methylene blue \\
5 & SO & $\mathrm{O}_{2}$ \\
& SDH & Methylene blue \\
24 & SO & $\mathrm{O}_{2}$ \\
& SDH & Methylene blue \\
& SDH & Phenazine methosulphate \\
48 & SDH & Methylene blue \\
& SDH & Phenazine methosulphate
\end{tabular}

\begin{tabular}{|c|c|c|}
\hline \multicolumn{2}{|c|}{$\begin{array}{c}\text { Uptake of } \mathrm{O}_{2} \\
(\mu \mathrm{l} .)\end{array}$} & \multirow{2}{*}{$\begin{array}{c}\text { Activity } \\
\text { lost } \\
\text { (\%) } \\
10 \mathrm{~min} .\end{array}$} \\
\hline $10 \mathrm{~min}$. & $60 \mathrm{~min}$. & \\
\hline $\begin{array}{l}47 \\
49 \\
53\end{array}$ & $\begin{array}{l}167 \\
122 \\
130\end{array}$ & - \\
\hline $\begin{array}{l}19 \\
45\end{array}$ & $\begin{array}{r}95 \\
131\end{array}$ & $\begin{array}{r}60 \\
8\end{array}$ \\
\hline $\begin{array}{l}12 \\
42\end{array}$ & $\begin{array}{r}50 \\
143\end{array}$ & $\begin{array}{l}75 \\
14\end{array}$ \\
\hline $\begin{array}{r}9 \\
42\end{array}$ & $\begin{array}{r}42 \\
132\end{array}$ & $\begin{array}{l}80 \\
14\end{array}$ \\
\hline $\begin{array}{r}0 \\
5 \\
23\end{array}$ & $\begin{array}{r}5 \\
26 \\
84\end{array}$ & $\begin{array}{r}100 \\
90 \\
57\end{array}$ \\
\hline $\begin{array}{r}0 \\
21\end{array}$ & $\begin{array}{r}9 \\
80\end{array}$ & $\begin{array}{r}100 \\
60\end{array}$ \\
\hline
\end{tabular}

more component than the phenazine system. Previously it had been shown that whereas Atabrine greatly inhibited succinoxidase activity and partially inhibited succinic dehydrogenase with either methylene blue or brilliant cresyl blue, it had no effect on the dehydrogenase as measured by the phenazine system (Eichel, 1956c). The differential behaviour of the two carriers towards the particulate dehydrogenase is reminiscent of the findings of Singer, Kearney \& Massey (1956) with soluble ox-heart succinic dehydrogenase. They concluded that whereas methylene blue requires at least one additional protein component, phenazine methosulphate reacts directly with the primary dehydrogenase.

It should be emphasized that the stability of the succinate system under study is increased as the complexity of the system is decreased by the use of autoxidizable dyes as terminal carriers in place of oxygen, and this parallels findings made with various DPNH-oxidizing enzymes (Eichel, 1956b). Diaphorase (dichlorophenolindophenol acceptor) is more stable than DPNH cytochrome c reductase, which, in turn, is considerably more stable than DPNH oxidase (oxygen acceptor); identical fall-off rates are seen with both DPNH oxidase and succinoxidase.

Effect of ageing homogenates at $0^{\circ}$ on the activities of glutamic and $\beta$-hydroxybutyric oxidases and glutamic and $\beta$-hydroxybutyric dehydrogenases

As expected, in homogenates aged at $0^{\circ}$ and assayed at varying times in the presence of DPN and glutamate or $\beta$-hydroxybutyrate, oxygen consumption declined rapidly and at a rate essentially parallel to the loss of succinoxidase activity. In the dehydrogenase systems, on the other hand, with phenazine methosulphate as the electron acceptor, the activity of aged homogenates towards glutamate and $\beta$-hydroxybutyrate fell by only $10-28 \%$ and $20-37 \%$ after 1 and 2 days respectively. When glutamic and $\beta$-hydroxybutyric dehydrogenases were measured spectrophotometrically by following the reduction of DPN at $340 \mathrm{~m} \mu$ in the presence of cyanide, neither enzyme lost activity for a period of at least $24 \mathrm{hr}$.

\section{Effect of heating homogenates on the activities of succinoxidase and succinic dehydrogenase}

Complete inactivation of the succinoxidase system occurred on heating the homogenates for $5 \mathrm{~min}$. at $37^{\circ}$ (Table 2). As with ageing at $0^{\circ}$, succinic dehydrogenase responded somewhat differently, depending upon the carrier used. Heattreatment for $5 \mathrm{~min}$. at $45^{\circ}$ destroyed almost all of the activity towards methylene blue but only a little more than half of that towards phenazine methosulphate, again suggesting that the system which methylene blue tests is more labile and, presumably, more complex. It has been reported (Eichel, 1956b) that heating homogenates for 5 min. at $35^{\circ}$ also destroyed $90 \%$ of the DPNH oxidase. Thus the extreme lability at $0^{\circ}$ of both oxidases was accentuated by heating the Tetrahymena preparations briefly at relatively low temperature. Glutamic and $\beta$-hydroxybutyric oxidases were also inactivated by heating homogenates for 5-10 min. at $30^{\circ}$. Results pertaining to the albumin experiments in Table 2 are described in the next section. 
Table 2. Effect of heating Tetrahymena pyriformis homogenates with and without crude bovine blood albumin on succinoxidase and succinic dehydrogenase activities

Enzyme activities were measured by the standard assays. Immediately after preparation the homogenates were heated as indicated with or without the crude albumin preparation in the final concentrations listed, and quickly cooled and assayed. The controls were unheated homogenates. Each Warburg vessel contained $1.95 \mathrm{mg}$. of homogenate $\mathrm{N}$ in the succinoxidase assay and $2 \cdot 27 \mathrm{mg}$. of homogenate $\mathrm{N}$ in the succinic dehydrogenase assays.

Enzyme system

Succinoxidase

Succinic dehydrogenase Methylene blue

Phenazine methosulphate
Conditions of heating

Control

5 min. at $37^{\circ}$

$10 \mathrm{~min}$. at $30^{\circ}$

5 min. at $37^{\circ}+3 \%$ of albumin

10 min. at $37^{\circ}+3 \%$ of albumin

Control

5 min. at $40^{\circ}$

5 min. at $45^{\circ}$

5 min. at $40^{\circ}+2 \%$ of albumin

Control

5 min. at $40^{\circ}$

5 min. at $45^{\circ}$

5 min. at $50^{\circ}$

5 min. at $40^{\circ}+2 \%$ of albumin

$\begin{array}{cc}\begin{array}{c}\text { Uptake } \\ \text { of } \mathrm{O}_{2}\end{array} & \begin{array}{c}\text { Activity } \\ \text { lost } \\ (\mu \mathrm{l} . / 10 \mathrm{~min} .)\end{array} \\ \begin{array}{c}(\%) \\ 30\end{array} & - \\ 1 & 97 \\ 5 & 83 \\ 25 & 17 \\ 19 & 37 \\ 56 & - \\ 28 & 50 \\ 2 & 97 \\ 57 & 0 \\ 48 & - \\ 32 & 33 \\ 20 & 58 \\ 1 & 98 \\ 57 & 0\end{array}$

Table 3. Effect of ageing Tetrahymena pyriformis homogenates at $0^{\circ}$ in the presence of crude bovine blood albumin on succinoxidase and succinic dehydrogenase activities

Enzyme activities were measured by the standard assays. In $A$ and $B$, fresh homogenate was added to a suspension of crude albumin in water to give the final albumin concentrations listed. Portions of these mixtures were then added to the Warburg vessels. All mixtures were assayed at the indicated intervals after preparation and were stored at $0^{\circ}$ throughout the experiments. Each vessel contained $1.62 \mathrm{mg}$. of homogenate $\mathrm{N}$.

\begin{tabular}{|c|c|c|c|c|}
\hline \multirow{3}{*}{$\begin{array}{l}\text { Concn. of } \\
\text { albumin } \\
(\%)\end{array}$} & \multicolumn{4}{|c|}{$\begin{array}{l}\text { A. Succinoxidase } \\
\text { Age of homogenate at assay (hr.) }\end{array}$} \\
\hline & 0 & 4 & 24 & 48 \\
\hline & \multicolumn{4}{|c|}{ Uptake of $\mathrm{O}_{2}(\mu \mathrm{l} . / 10 \mathrm{~min})}$. \\
\hline 0 & 21 & 8 & 0 & 0 \\
\hline 0.5 & 25 & 16 & 4 & 0 \\
\hline 1 & 25 & 22 & 11 & 2 \\
\hline 2 & 20 & 25 & 18 & 5 \\
\hline
\end{tabular}

$B$. Succinic dehydrogenase

Age of homogenate at assay (hr.)

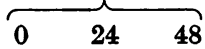

Concn. of Uptake of $\mathrm{O}_{2}$

Electron acceptor Phenazine methosulphate albumin ( $\mu \mathrm{l} . / 10 \mathrm{~min}$. (\%)

Methylene blue
Stabilization of succinoxidase, succinic dehydrogenase and reduced diphosphopyridine nucleotide oxidase activities by a crude bovine albumin preparation

The results of a typical experiment, presented in Table $3 A$, show that the addition of a crude bovine blood-albumin preparation to a freshly prepared homogenate, in a final concentration of $2 \%$, prevented the loss of succinoxidase activity for about $24 \mathrm{hr}$. in homogenate allowed to age at $0^{\circ}$. (In the experiment illustrated, the concentration of the albumin powder in the vessels was $0.4 \%$.) Stabilization could be extended to at least $43 \mathrm{hr}$. by adding $5 \%$ of albumin to a fresh homogenate. In the absence of added succinate, a $2 \%$ albuminhomogenate mixture consumed only $4 \mu \mathrm{l}$. of oxygen in $10 \mathrm{~min}$. In the absence of both succinate and homogenate there was no oxygen uptake by the albumin preparation.

Succinic dehydrogenase activity, measured with either phenazine methosulphate or methylene blue, was also stabilized (Table $3 B$ ). Although it would seem plausible that the apparent activation of the dehydrogenase at zero time by the crude albumin powder was due to the oxidation of various substrates present in the powder, with the dyes serving as carriers, the fact that similar results were obtained with crystalline albumin (see below) might indicate some other effect was responsible for the stimulation. Whether the decline in activity at $24 \mathrm{hr}$. in the presence of the crude albumin represented the loss of this enhanced activity or a partial 
loss of the original succinic dehydrogenase or both was not examined.

Stabilization of both succinoxidase and succinic dehydrogenase activities against heat-inactivation, by heating homogenates at $37^{\circ}$ or $40^{\circ}$ in the presence of the crude albumin preparation, is shown in Table 2.

The DPNH oxidase system is also stabilized by the albumin preparation. The results of Table 4 indicate that in water homogenates about $90 \%$ of the DPNH oxidase activity was preserved in homogenate-albumin mixtures $24 \mathrm{hr}$. after storage at $0^{\circ}$, and $50 \%$ remained after 2 days. It is possible that higher concentrations $(>7.5 \%)$ of the albumin extract would protect the oxidase to a greater degree for a longer time. In other experiments not tabulated, DPNH cytochrome $c$ reductase acitivty of homogenates aged at $0^{\circ}$ decreased $30-40 \%$ after $6 \mathrm{hr}$., $45-60 \%$ after $24 \mathrm{hr}$. and $90 \%$ after $72 \mathrm{hr}$. The crude albumin stabilized the DPNH cytochrome $c$ reductase activity completely for at least $72-96 \mathrm{hr}$.

Table 4. Effect of ageing Tetrahymena pyriformis homogenates at $0^{\circ}$ in the presence of crude bovine blood albumin on reduced diphosphopyridine nucleotide oxidase activity

DPNH oxidase activity was measured by the standard assay described in the Experimental section. With the 'water homogenate', cells were washed and homogenized in water and $2 \mathrm{ml}$. portions of homogenate $(1.92 \mathrm{mg}$. of $\mathrm{N} / \mathrm{ml}$.) were added to test tubes containing the indicated amount of a lyophilized extract of the crude albumin (see Results section for its preparation). After thorough mixing, each sample was assayed immediately and at the intervals shown. With the 'phosphate homogenate', cells were washed twice in water, once in $0.1 \mathrm{M}-\mathrm{KH}_{2} \mathrm{PO}_{4}-\mathrm{K}_{2} \mathrm{HPO}_{4}$ buffer, $\mathrm{pH} \mathrm{8.2}$, and homogenized in $0.05 \mathrm{M}-\mathrm{KH}_{2} \mathrm{PO}_{4}-$ $\mathrm{K}_{2} \mathrm{HPO}_{4}$, $\mathrm{pH} 8 \cdot 2$. Portions of homogenate were again added to the lyophilized extract and assayed as before. All homogenate mixtures were stored at $0^{\circ}$ throughout the experiments. The values are given as $10^{3} \Delta E_{340 \mathrm{~m} \mu} / 2 \mathrm{~min}$.

\begin{tabular}{|c|c|c|c|c|}
\hline \multirow{3}{*}{ Albumin } & \multicolumn{4}{|c|}{ Age at assay (hr.) } \\
\hline & 0 & $5 \cdot 5$ & 24 & 48 \\
\hline & \multicolumn{4}{|c|}{ Water homogenate } \\
\hline 0 & 191 & 18 & 8 & 4 \\
\hline 10 & 178 & 153 & 20 & 8 \\
\hline 30 & 196 & 161 & 84 & 16 \\
\hline 60 & 170 & 194 & 140 & 62 \\
\hline 90 & 191 & 193 & 151 & 86 \\
\hline 120 & 177 & 210 & 151 & 94 \\
\hline \multirow[t]{2}{*}{150} & 175 & 209 & 156 & 94 \\
\hline & \multicolumn{4}{|c|}{ Phosphate homogenate } \\
\hline 0 & 98 & 113 & 73 & 31 \\
\hline 5 & 122 & 115 & 73 & 33 \\
\hline 10 & 123 & 117 & 81 & 45 \\
\hline 20 & 124 & 119 & 90 & 53 \\
\hline 30 & 122 & 118 & 94 & 59 \\
\hline 60 & 117 & 125 & 109 & 75 \\
\hline
\end{tabular}

It had been pointed out previously that homogenizing whole Tetrahymena cells in alkaline phosphate buffer prevented the loss of DPNH oxidase activity for periods up to $24 \mathrm{hr}$. The results in Table 4 show that the stabilizing action of the alkaline phosphate and of the crude albumin are essentially additive and suggest that stabilization of the oxidase for longer periods might be achieved by combination of the two agents and increasing the albumin concentration.

Stabilization of the succinoxidase system of rat-liver homogenate by the crude bovine-albumin preparation

It was of interest to determine whether the albumin preparation could also stabilize the aerobic oxidation of succinate by a mammalian tissue. Rat-liver homogenate ( $5 \mathrm{ml}$; $1.3 \mathrm{mg}$. of $\mathrm{N} / \mathrm{ml}$.) was mixed with $5 \mathrm{ml}$. of a $1 \%$ suspension of albumin. A control, without albumin, was similarly prepared. Whereas the rat-liver-homogenate system was far more stable than that of Tetrahymena, there was protection against the loss of succinoxidase activity on ageing at $0^{\circ}$. At 48 and $120 \mathrm{hr}$., when 45 and $91 \%$ of the control activity was lost respectively, only 13 and $42 \%$ of the activity of the albumin-protected homogenate disappeared.

Specificity of the crude bovine-albumin preparation

To determine whether the stabilization conferred by the crude albumin preparation was characteristic of proteins in general, several purified proteins were tested with the Tetrahymena succinoxidase system. The results are presented in Table 5 . Whereas crude preparations of haemoglobin and human serum albumin had some stabilizing activity, neither purified (fraction $V$ powder) nor crystallized bovine plasma albumin was effective. In fact, at $2 \%$ the latter preparations were inhibitory at zero time. Crystalline albumin was not only incapable of preventing the loss of succinic dehydrogenase activity on ageing at $0^{\circ}$, but after $24 \mathrm{hr}$. was markedly inhibitory. At zero time, however, the crystalline albumin stimulated succinic dehydrogenase considerably with the phenazine methosulphate and methylene blue tests. Both proteose peptone and yeast extract gave considerable protection of the succinoxidase system. In the presence of 1 or $2 \%$ of peptone or yeast extract, homogenates lost little activity after ageing for $5 \mathrm{hr}$. at $0^{\circ}$, but lost $50 \%$ or more after $24 \mathrm{hr}$. The glutamic and $\beta$-hydroxybutyric oxidase systems were both stabilized by the yeast extract and the peptone.

From the results of Table 5 it can be concluded that the stabilizing action of the crude albumin preparation (Table 3) is due to an impurity and not to the albumin. The presence of trace amounts of this material is suggested in the haemoglobin and 


\section{Table 5. Effect of ageing Tetrahymena pyriformis homogenates at $0^{\circ}$ in the presence of various purified proteins on succinoxidase activity}

Succinoxidase activities were measured by the standard assay. Homogenates were added to the proteins to give the final protein concentrations listed. Portions of these mixtures were then added to the Warburg vessels, and the mixtures were reassayed after being stored for $24 \mathrm{hr}$. at $0^{\circ}$.

\begin{tabular}{|c|c|c|}
\hline Protein & $\begin{array}{l}\text { Concn. } \\
(\%, w / v)\end{array}$ & $\begin{array}{c}\text { after } 24 \mathrm{hr} . \\
(\%)\end{array}$ \\
\hline Gelatin & 2,3 , or 4 & 100 \\
\hline Haemoglobin* & 2,3, or 4 & 65 \\
\hline Human serum albumin $†$ & $0 \cdot 5,1,2$, or 3 & $76($ at $3 \%)$ \\
\hline Human serum $\gamma$-globulin $\ddagger$ & $0.5,1,2$, or 3 & 95 (at $3 \%$ ) \\
\hline Proteose peptone $\S$ & 1 or 2 & 53 \\
\hline Casein & 1 or 2 & 100 \\
\hline Purified bovine-plasma albuminj| & $0.5,1,2$, or 3 & $100 * *$ \\
\hline Crystalline bovine albumin $\rrbracket$ & $0 \cdot 13,0 \cdot 5,1,2$, or 3 & $100 * *$ \\
\hline $\begin{array}{l}\text { Nutritional Biochemicals Corp. } \\
\text { Fraction II; E. R. Squibb and Sons. } \\
\text { Fraction V; Armour and Co. }\end{array}$ & \multicolumn{2}{|c|}{$\begin{array}{ll}\dagger & \text { Fraction V; E. R. Squibb and Sons. } \\
\S & \text { Difco. } \\
\uparrow & \text { Four times recrystallized; Armour and Co. }\end{array}$} \\
\hline
\end{tabular}

human serum-albumin samples used; proteose peptone and yeast extract (not tabulated) apparently contain a considerable amount of it.

\section{Presence of the stabilizing activity in blood}

Since the supply of the crude albumin preparation, which was at least 2-3 years old, was limited, a newly received lot of the crude bovine albumin was tested and found to contain the stabilizing activity. In the absence of information about the method of preparation of the crude alburnin, it was important to determine whether its stabilizing activity was due to a naturally occurring material or one added during the course of separation of the albumin from blood. Hence blood serum and plasma from several sources were tested for stabilizing activity towards the succinoxidase system of aged Tetrahymena homogenates. When $2.5 \mathrm{ml}$. of diluted rat serum $(1 \mathrm{ml}$. of serum plus $1.5 \mathrm{ml}$. of water) were added to $2.5 \mathrm{ml}$. of homogenate ( $2 \mathrm{mg}$. of $\mathrm{N} / \mathrm{ml}$.), 70-100\% of the succinoxidase activity was preserved for at least $24 \mathrm{hr}$. Horse, human and chick serum were all active.

\section{Some properties of the stabilizing material}

In the foregoing studies, a known amount of the crude albumin preparation was generally suspended in glass-distilled water and allowed to stand for $1 \mathrm{hr}$. in the cold before adding the homogenate to it. However, since the albumin preparation was only partially soluble, the following experiment was carried out to determine with which fraction the protective activity was associated. Crude albumin (300 mg.) was suspended in $5 \mathrm{ml}$. of water, and allowed to stand for $1 \mathrm{hr}$. in the cold and centrifuged at $110800 \mathrm{~g}$ for $20 \mathrm{~min}$. A volume $(2.5 \mathrm{ml}$.) of the pale-yellow supernatant fluid was added to $2.5 \mathrm{ml}$. of homogenate. The viscous sediment was suspended in $5 \mathrm{ml}$. of cold water and $2.5 \mathrm{ml}$. of the suspension added to $2.5 \mathrm{ml}$. of homogenate. After $24 \mathrm{hr}$., $50 \%$ of the original succinoxidase activity remained in the homogenate-supernatant fluid mixture and $30 \%$ in the homogenate-sediment sample, indicating that a considerable amount of the protective material could be extracted by water. On a dry wt. basis, about 15-20\% of the crude albumin preparation was extracted under these conditions. The extract could be lyophilized without the loss of its stabilizing activity.

In Table 6 are summarized the results of a number of replicate experiments which show that the stabilizing activity of the albumin extract was unaffected by heating at $100^{\circ}$ for $10 \mathrm{~min}$. at either neutrality or $\mathrm{pH} \mathrm{4.5}$, or by adjustment to $\mathrm{pH} \mathbf{1 0 . 4}$

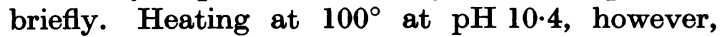
appeared to destroy the activity almost completely, although a small amount of protection was achieved in some experiments. Heating albumin extract in more dilute solutions destroyed some of its protective activity, but heating for $30 \mathrm{~min}$. at $100^{\circ}$ had no more effect than heat treatment for $10 \mathrm{~min}$. It was also noted that the initial succinoxidase activity of the mixture of homogenate and boiled alkalinized extract was very low, suggesting the possibility that some inhibitory material was released which, in turn, prevented or masked the stabilizing activity. Dialysis of the albumin extract against glass-distilled water resulted in the complete loss of stabilizing activity. Lyophilized diffusate ( $7 \mathrm{mg} . / \mathrm{ml}$. of $1: 2$ homogenate) was effective in protecting against the loss of succinoxidase activity, although in a few experiments the stabilization was less after $24 \mathrm{hr}$. than after $5 \mathrm{hr}$. Heating lyophilized diffusate for as long as $30 \mathrm{~min}$. at $100^{\circ}$ caused only a slight decrease in the stabilizing effect. In other experiments not listed in Table 6, it was shown that the stabilizing action of rat serum, yeast extract and proteose peptone 
towards succinoxidase and $\beta$-hydroxybutyric oxidase was markedly reduced by dialysis, and human blood plasma, heated at $100^{\circ}$ for $30 \mathrm{~min}$. and then centrifuged to remove denatured protein, lost none of its stabilizing activity.

\section{Essential irreversibility of the loss of succinoxidase activity}

The addition of crude albumin preparation to Warburg vessels containing homogenate which had

Table 6. Effect of different treatments of crude albumin extract on its ability to stabilize the succinoxidase activity of Tetrahymena pyriformis homogenates

Lyophilized albumin extract (700 mg.) was dissolved in $25 \mathrm{ml}$. of water (pH 7-1). One portion (5 ml.) was brought to $\mathrm{pH} \mathrm{10.4} \mathrm{with} \mathrm{N}-\mathrm{KOH}$ and another to $\mathrm{pH} 4.55$ with $\mathrm{N}-\mathrm{HCl}$, and both samples were heated in a boiling-water bath for $10 \mathrm{~min}$. The samples were then chilled and immediately brought to $\mathrm{pH} 6 \cdot 5-6 \cdot 7$. A third portion (5 ml.) was adjusted to $\mathrm{pH} 10 \cdot 4$, allowed to stand for $10 \mathrm{~min}$. at room temperature, and then readjusted to $\mathrm{pH} 6 \cdot 6$. A fourth sample was simply heated $\left(100^{\circ}\right)$ for $10 \mathrm{~min}$. at $\mathrm{pH} 7 \cdot 1$, and then chilled, and a fifth was untreated. To $\mathbf{1 . 5} \mathrm{ml}$. of each of the above portions of albumin extract was added $1.5 \mathrm{ml}$. of protozoan homogenate $(4.14 \mathrm{mg}$. of $\mathrm{N})$; each mixture was assayed immediately and after standing for $5 \mathrm{hr}$. at $0^{\circ}$.

In the experiments dealing with the dialysed extracts and diffusates, $10 \mathrm{ml}$. of albumin extract $(30 \mathrm{mg}$. $/ \mathrm{ml}$.) was dialysed against $165 \mathrm{ml}$. of glass-distilled water in the cold with constant stirring. After $18 \mathrm{hr}$., $5 \mathrm{ml}$. of the extract was removed, and the remainder was dialysed for an additional $18 \mathrm{hr}$. against fresh distilled water. The first diffusate was lyophilized and dissolved in $9 \mathrm{ml}$. of water. A portion (4 ml.) of this solution was added to $4 \mathrm{ml}$. of homogenate $(2.5 \mathrm{mg}$. of $\mathrm{N} / \mathrm{ml}$.); a portion $(2.5 \mathrm{ml}$.) was heated at $100^{\circ}$ for $30 \mathrm{~min}$., and chilled and added to $2.5 \mathrm{ml}$. of the same homogenate; each mixture and a control were assayed immediately and after standing for $5 \mathrm{hr}$. at $0^{\circ}$. In this experiment, the lyophilized diffusate was not weighed. Generally, it was found that under these conditions about $42 \%$ of the albumin extract was present in the diffusate or, in this case, $126 \mathrm{mg}$. Therefore $7 \mathrm{mg}$. of lyophilized diffusate was mixed with each millilitre of diluted homogenate.

\section{Additions to homogenate}

Activity lost in $5 \mathrm{hr}$.

None (\%)

Extract

Boiled extract

Alkalinized extract (pH 10.4)

Boiled alkalinized extract

Boiled acidified extract (pH 4.55)

Extract dialysed $18 \mathrm{hr}$.

Extract dialysed $36 \mathrm{hr}$.

Lyophilized diffusate of extract Lyophilized diffusate of extract, boiled $30 \mathrm{~min}$. been aged for $20 \mathrm{hr}$. at $0^{\circ}$ failed to restore the succinoxidase activity, although some oxygen uptake was registered above the control level. This suggested that the loss of succinoxidase activity was largely irreversible and that the activity present at a given time after preparation of the homogenate was a function of the time of addition of the crude albumin preparation. The results presented in Fig. 1 illustrate this effect in greater detail. In this experiment, the water control lost little activity in the first hour, but thereafter activity declined at the more typical rate. Albumin extract added to homogenate at zero time stabilized the succinoxidase activity for at least $5 \mathrm{hr}$. essentially at the initial level and for $24 \mathrm{hr}$. at $85 \%$ of the initial level. On the other hand, addition of extract to homogenate at 3 or $5 \mathrm{hr}$. did not restore the activity already lost, but did preserve the activity remaining at the time extract was added. The somewhat higher activities of the extract-homogenate mixtures prepared at 3, 5 and $24 \mathrm{hr}$. compared with the water control assayed at these times may represent a small reversal of the inactivation.

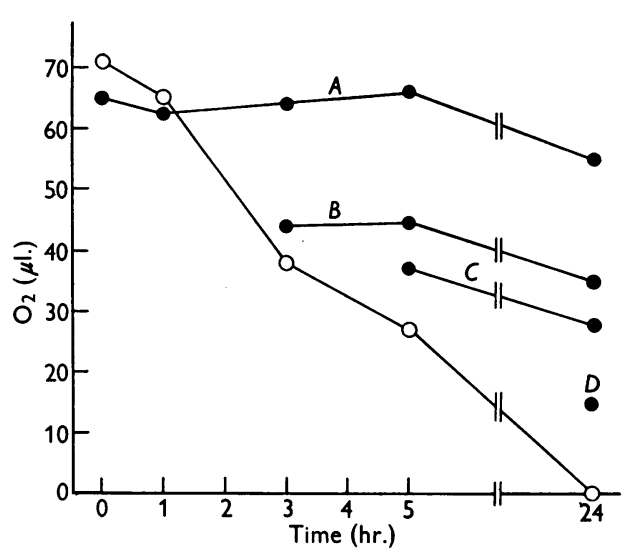

Fig. 1. Effect on succinoxidase activity of adding crude albumin extract to Tetrahymena homogenate at varying intervals after preparation of homogenate. Immediately after homogenizing the cells, a portion of homogenate was mixed with an equal volume of water (the control, $\mathrm{O})$, a second portion was mixed with an equal volume of albumin extract (O), and both samples were assayed immediately for succinoxidase activity and also at 1, 3, 5 and $24 \mathrm{hr}$. thereafter. Other portions of the original homogenate were also diluted 1:2 with extract at 3,5 and $24 \mathrm{hr}$., and each mixture was assayed immediately after its preparation as well as at the indicated times. All homogenates were stored at $0^{\circ}$ throughout. Curves $A, B$ and $C$ represent results obtained when the extract was added to homogenate at 0,3 and $5 \mathrm{hr}$. respectively. The point labelled $D$ represents the activity obtained when the extract was added after $24 \mathrm{hr}$. 


\section{Failure of certain compounds to stabilize the succinoxidase system}

Attempts to reproduce the action of the crude albumin preparation by adding to fresh homogenates various compounds, which have been implicated in electron-transport function or which occur in blood plasma, were more or less unsuccessful. Thus adenosine triphosphate (3 mM); cholesterol (4.2 $\mathrm{mm}$ ); animal or vegetable lecithin (1 mg./ml. of homogenate); riboflavin phosphate (1.7 mM); a mixture of $21 \mathrm{~L}$-amino acids (40 $\mu \mathrm{g}$. of each in $5 \mathrm{ml}$. of homogenate); larger concentrations of histidine (32 $\mathrm{mm})$, cysteine $(6 \mathrm{~mm})$ or tryptophan (8 $\mathrm{mM})$; uridine triphosphate $(0.7 \mathrm{~mm})$; bilirubin $(0.1 \mathrm{mg} . / 5 \mathrm{ml}$. of homogenate); glucose $(0.05 \mathrm{M}$, $0.25 \mathrm{M}) ; \mathrm{NaCl}(0.05 \mathrm{M}, 0.25 \mathrm{M})$; ascorbic acid (5 mM); $\mathrm{Mg}^{2+}, \mathrm{Fe}^{2+}, \mathrm{Fe}^{3+}, \mathrm{Cu}^{2+}$ ions (all 0.055.0 mM); $\mathrm{Mn}^{2+}, \mathrm{Cu}^{+}$ions (each $5 \mathrm{~mm}$ ); and a suspension of haemin $(2 \mathrm{mg} . / \mathrm{ml}$. of homogenate) failed to stabilize the succinoxidase activity of homogenates aged at $0^{\circ}$. Since the absorption spectrum of the lyophilized diffusate of the crude albumin extract exhibited a very broad plateau in the region $250-280 \mathrm{~m} \mu$, a number of nucleic acid derivatives were also tested for activity. Inosine, uridine, cytidine and adenine were without effect, but a mixture of adenylic acid $a$ and $b$ or adenosine alone gave some stabilization and to about the same extent. After $20 \mathrm{hr}$. at $0^{\circ}$, whereas the control lost $90-96 \%$ of the initial activity the adenylic acid- or adenosine-supplemented homogenates lost only 60-80\%. Liver-extract powder also partly stabilized the succinoxidase system.

Effect of succinate on the stabilization of succinoxidase and succinic dehydrogenase activities of heated and aged $\left(0^{\circ}\right)$ homogenates of Tetrahymena pyriformis

In part 1 of this series (Eichel, 1954), the aerobic oxidation of succinate by homogenates of Tetrahymena was studied by equilibrating pre-chilled Warburg vessels, which contained succinate in the side arms and a homogenate-buffer mixture in the main compartments, for 5 min. at $30^{\circ}$, and tipping in the succinate and then closing the manometers after an additional $5 \mathrm{~min}$. Later, it was observed that the oxygen consumption of such a system could be increased considerably during the first $10 \mathrm{~min}$. period simply by adding the succinate to the homogenate and buffer in the main compartments of vessels maintained in an ice bath and then equilibrating the vessels at $30^{\circ}$ before closing the manometers. This procedure has been employed in more recent work dealing with the succinoxidase system (Eichel, 1955, 1956c). The greater activity obtained by mixing all components at $0^{\circ}$ before equilibration at $30^{\circ}$ was interpreted as being due either to substrate activation or to substrate protection of the enzyme system, but this point was not pursued further at the time. The demonstration of an extremely rapid inactivation of succinoxidase and DPNH oxidase activities by heating at $30^{\circ}$ or by ageing at $0^{\circ}$, and the stabilization of these electron transport systems by a crude bloodalbumin preparation or blood serum, prompted a more detailed investigation into the effects of heating and ageing, with and without succinate, on the succinoxidase and DPNH oxidase systems. Homogenate-phosphate buffer mixtures which were equilibrated in the Warburg bath for as little as $6 \mathrm{~min}$. at $30^{\circ}$ before receiving sodium succinate lost half of their succinoxidase activity. The degree of inactivation under these conditions was quite variable, but always severe, and generally ranged from 35 to $60 \%$ after 5-6 $\mathrm{min}$. However, when $2 \mathrm{ml}$. of fresh homogenate $(4 \cdot 16 \mathrm{mg}$. of $N)$ was heated for $10 \mathrm{~min}$. at $30^{\circ}$ with succinate in a final concentration of $34.8 \mathrm{~mm}$, and cooled and then assayed under the usual test conditions, there was no loss of enzyme activity compared with unheated homogenate. Heating for $30 \mathrm{~min}$. at $30^{\circ}$ with the same amount of succinate caused only a $10 \%$ drop in activity, which was unaltered by doubling the succinate concentration. With $67 \mathrm{~mm}$-succinate in the presence of $4.28 \mathrm{mg}$. of homogenate $\mathrm{N}$, heating for $10 \mathrm{~min}$. at $35^{\circ}$ resulted in very little enzyme inactivation $\left(-8 \%\right.$ ), but at $40^{\circ}$ a $59 \%$ decrease in activity was found. The latter value was halved when the succinate concentration was raised to $0 \cdot 231 \mathrm{M}$.

Succinic dehydrogenase activity measured with phenazine methosulphate was also protected when homogenates were heated in the presence of succinate. Under the latter conditions, even after $10 \mathrm{~min}$. at $45^{\circ}, 44 \%$ of the dehydrogenase activity remained; only $17 \%$ of the activity was left after heating for $10 \mathrm{~min}$. without succinate.

Addition of succinate to homogenates aged at $0^{\circ}$ also prevented the rapid inactivation of the succinoxidase system. Incubation of homogenate $(2.05 \mathrm{mg}$. of $\mathrm{N} / \mathrm{ml}$.) with added succinate in a final concentration of $9 \cdot 16 \mathrm{~mm}$ gave complete stabilization for $4.5 \mathrm{hr}$. and resulted in the loss of only $18 \%$ of the original activity after $24 \mathrm{hr}$. (Table 7). At $0.154 \mathrm{~mm}$-succinate, half of the activity was preserved for $4.5 \mathrm{hr}$. but none remained after $24 \mathrm{hr}$. In some cases, complete stabilization was achieved for $48 \mathrm{hr}$. at $35 \mathrm{~mm}$-succinate. Solutions of succinic acid adjusted to $\mathrm{pH} 7 \cdot 0$ with either dilute $\mathrm{KOH}$ or $\mathrm{NaOH}$ behaved like commercial sodium succinate.

After succinate-stabilized homogenates (18.9 mM) were centrifuged at $73300 \mathrm{~g}$ for $30 \mathrm{~min}$. and the pellet, containing all of the succinoxidase activity (Eichel, 1955), was resuspended in water, ageing of the glass-homogenized pellet at $0^{\circ}$ for $24 \mathrm{hr}$. 
resulted in nearly complete inactivation of the succinoxidase system. However, addition of succinate to the homogenized pellet immediately after its preparation preserved for at least $19 \mathrm{hr}$. the succinoxidase activity present at the time succinate was added. The abolition of the stabilizing effect by the centrifuging of succinate-supplemented homogenates indicates that the succinate is readily dissociated from its binding site(s) on the particles. In a similar experiment, it was found that when homogenate was stabilized with both succinate (18.9 $\mathrm{mm})$ and lyophilized albumin

Table 7. Effect of ageing Tetrahymena pyriformis homogenate at $0^{\circ}$ in the presence of sodium succinate on succinoxidase activity

Portions (4 ml.) of fresh homogenate (2.05 mg. of N/ml.) were incubated with $0.5 \mathrm{M}$-sodium succinate to give the final concentrations listed. Samples of these mixtures were then added to the vessels. All mixtures were assayed at the indicated intervals after preparation and were stored at $0^{\circ}$ between assays. The figures represent uptake of oxygen for the first $10 \mathrm{~min}$. after closing the manometers $(a)$ and for the first hour $(b)$.

\begin{tabular}{|c|c|c|c|c|c|c|}
\hline \multirow{4}{*}{$\begin{array}{l}\text { Final } \\
\text { concn. of } \\
\text { succinate } \\
\text { (mM) }\end{array}$} & \multicolumn{6}{|c|}{ Age of homogenate at assay (hr.) } \\
\hline & \multicolumn{2}{|c|}{0} & \multicolumn{2}{|c|}{$4 \cdot 5$} & \multicolumn{2}{|c|}{24} \\
\hline & (a) & (b) & (a) & (b) & (a) & (b) \\
\hline & \multicolumn{6}{|c|}{ Uptake of $\mathrm{O}_{2}(\mu \mathrm{l})}$. \\
\hline 0 & & & 12 & 71 & 0 & 9 \\
\hline $17 \cdot 4$ & 34 & 174 & 33 & 173 & 33 & 157 \\
\hline $9 \cdot 16$ & 34 & 175 & 33 & 176 & 28 & 117 \\
\hline 1.25 & 35 & 181 & 29 & 148 & 2 & 14 \\
\hline $0 \cdot 308$ & 36 & 180 & 21 & 117 & 0 & 10 \\
\hline $0 \cdot 154$ & 37 & 192 & 17 & 89 & 0 & 11 \\
\hline
\end{tabular}

extract, and centrifuged and the resultant pellet homogenized in water, only about $23 \%$ of the initial activity was present in the pellet after $24 \mathrm{hr}$. of ageing at $0^{\circ}$.

\section{Effects of other compounds on the stabilization of succinoxidase activity}

A number of compounds, many of which are closely related to succinic acid structurally, were tested for their ability to stabilize the complete succinoxidase system in homogenates aged at $0^{\circ}$. They were fumarate, malate, $\alpha$-oxoglutarate, pyruvate, acetate, malonate, isocitrate, citrate, formate, oxalate, tartrate, glutarate, adipate, butyrate, glutamate, succinylcholine chloride, choline, succinimide, mercaptosuccinate and pyrophosphate. None of these compounds caused significant oxygen uptake under the experimental conditions in the absence of added succinate. Of the 20 compounds, only isocitrate, citrate, succinylcholine and succinimide gave appreciable protection (Table 8). isoCitrate was most effective; at low concentration (35 mM), homogenates lost only $10 \%$ of the enzyme activity after $5 \mathrm{hr}$. At $0 \cdot 136 \mathrm{M}$, isocitrate-fortified homogenates lost $42 \%$ of the activity after $24 \mathrm{hr}$. Citrate was somewhat less effective. Succinylcholine gave almost complete stabilization for $5 \mathrm{hr}$. at $67 \mathrm{~mm}$, but had little effect at twice this level after $24 \mathrm{hr}$. Choline alone was ineffective, and did not inhibit the stabilization by succinate. Hence the failure of succinylcholine to protect at $24 \mathrm{hr}$. could not be due to the presence of any free choline that might have been formed by hydrolysis. Partial protection was conferred by succinimide at high concentration

\section{Table 8. Effect of ageing Tetrahymena pyriformis homogenates in the presence of various compounds on succinoxidase activity}

Results listed are taken from a number of experiments in which many different homogenate preparations were employed. In each experiment, volumes of $0.5 \mathrm{M}$-solution of the compound to be tested were added to portions ( $2 \mathrm{ml}$.) of homogenate to give the final concentrations indicated, and the mixtures were assayed immediately and after $5 \mathrm{hr}$. $(a)$ or $24 \mathrm{hr}$. (b) or both. All of the compounds tested were adjusted to $\mathrm{pH} \mathrm{7.0} \mathrm{with} \mathrm{either} \mathrm{dilute} \mathrm{acid} \mathrm{or} \mathrm{base} \mathrm{before} \mathrm{adding} \mathrm{to} \mathrm{homogenate,}$ and all homogenate mixtures were aged at $0^{\circ}$ throughout. In each experiment one or more controls, to which several volumes of water were added, were run. Control homogenates lost $65-85 \%$ of their original succinoxidase activity after $5 \mathrm{hr}$. and $95-100 \%$ after $24 \mathrm{hr}$. Homogenates aged in the presence of $17 \cdot 4$ mM-succinate lost no activity after $24 \mathrm{hr}$. Total $\mathrm{N}$ content of the homogenates used ranged from $1 \cdot 60$ to $2 \cdot 20 \mathrm{mg} . / \mathrm{ml}$.

\begin{tabular}{|c|c|c|c|c|c|c|c|}
\hline \multicolumn{8}{|c|}{ Concn. (mM) } \\
\hline \multicolumn{2}{|c|}{18} & \multicolumn{2}{|c|}{35} & \multicolumn{2}{|c|}{67} & \multicolumn{2}{|c|}{136} \\
\hline (a) & $(b)$ & (a) & (b) & (a) & (b) & (a) & (b) \\
\hline \multicolumn{8}{|c|}{ Succinoxidase activity lost after ageing for 5 and $24 \mathrm{hr}$. at $0^{\circ}(\%)$} \\
\hline- & - & 10 & 80 & - & - & 31 & 42 \\
\hline 35 & 88 & 42 & 65 & 47 & 65 & 67 & 55 \\
\hline 70 & - & 51 & - & 15 & 87 & 4 & 86 \\
\hline 70 & - & 70 & - & 60 & 100 & 46 & 92 \\
\hline 37 & - & 50 & - & - & - & - & - \\
\hline
\end{tabular}

Sodium isocitrate

Sodium citrate

Succinylcholine chloride

Succinimide

Sodium pyrophosphate

37

70
50 
Table 9. Effect of ageing Tetrahymena pyriformis homogenates in the presence of various compounds on reduced diphosphopyridine nucleotide oxidase activity

Results listed are taken from a number of experiments in which many different homogenate preparations were employed. Experimental conditions were exactly as described in Table 4. Total $\mathbf{N}$ content of the homogenates used ranged from 1.54 to $1.79 \mathrm{mg} . / \mathrm{ml}$.

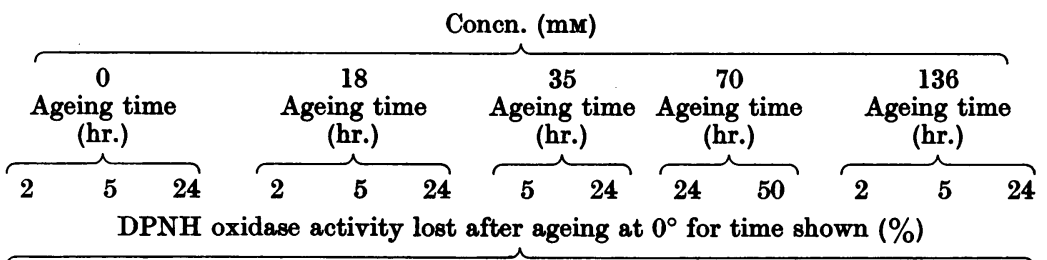

Compound tested

\section{None}

Sodium succinate

Sodium citrate

Sodium isocitrate

Malic acid

Sodium malonate

$\begin{array}{lllllllllllll}63 & 89 & 96 & - & - & - & - & \overline{1} & - & \overline{1} & - & - & - \\ - & - & - & 0 & 0 & 25 & 0 & 21 & 16 & 53 & \overline{3} & \overline{4} & - \\ - & - & - & 41 & 58 & 82 & - & - & - & - & 31 & 41 & 62 \\ - & - & - & 33 & 63 & 86 & - & - & - & - & 11 & 15 & 44 \\ - & - & - & 54 & 79 & 97 & - & - & - & - & - & \frac{1}{70} & \overline{97}\end{array}$

$(0.136 \mathrm{M})$ for $5 \mathrm{hr}$, but very little protection was obtained after $24 \mathrm{hr}$. with this compound. Ethylenediaminetetra-acetic acid ( $63 \mathrm{~mm})$, which has been used to stabilize various enzymic activities in animal and plant preparations, gave negative results, as did gum arabic $(1.7 \%)$ and sucrose $(0 \cdot 05-0 \cdot 25 \mathrm{M})$.

Many of the compounds listed above inhibited succinoxidase activity at zero time at the higher concentrations and, in some instances, inhibition obtained at low levels prevented the testing at higher concentrations. isoCitrate gave 20 and $50 \%$ inhibition at 0.045 and $0.136 \mathrm{M}$ respectively, whereas citrate inhibited $62 \%$ at the latter concentration. Fumarate, malate, $\alpha$-oxoglutarate, glutarate, adipate and pyruvate inhibited succinoxid. ase activity by $20-40 \%$ at $6.7 \mathrm{~mm}$. Formate, oxalate and tartrate gave $30-38 \%$ inhibition at $0 \cdot 136 \mathrm{M}$. Malonate, as might be expected, gave 35 and $70 \%$ inhibition at 6.2 and $18 \mathrm{~mm}$ respectively. At 6.2 mM-malonate, slight protection was achieved. Mercaptosuccinate inhibited activity by $35 \%$ at $18 \mathrm{~mm}$, and succinylcholine inhibited by $30 \%$ at $0 \cdot 136 \mathrm{M}$. Pyrophosphate, reported to have a specific protective effect on succinic dehydrogenase and other enzymes (Morton, 1955), stabilized the succinoxidase system considerably after $5 \mathrm{hr}$. (Table 8), but also inhibited the initial activity by $40 \%$ at the same concentration (18 mM). At twice this concentration, stabilization by pyrophosphate was lessened, and the inhibition rose to $60 \%$. It should be noted that the concentrations of all compounds tested as potential stabilizers refer only to the final concentrations of the aged homogenate-compound mixtures. The actual concentration of each compound present in the vessels during assay was less by a factor of $5 \cdot 6$.
Effects of succinate and other compounds on the stabilization of reduced diphosphopyridine nucleotide oxidase and reduced diphosphopyridine nucleotide cytochrome c reductase activities of aged and heated homogenates of Tetrahymena pyriformis

Table 9 summarizes a number of experiments in which the effective stabilizers of the succinoxidase system were tested for their ability to protect the DPNH oxidase system against inactivation on ageing at $0^{\circ}$. It can be seen that succinate $(18 \mathrm{~mm})$ prevented the loss of DPNH oxidase activity completely for at least $5 \mathrm{hr}$., and at $70 \mathrm{~mm}$ preserved 84 and $47 \%$ of the activity after 24 and $50 \mathrm{hr}$. respectively. In low concentration, isocitrate and citrate were somewhat effective, and in higher concentration, both tricarboxylic acids gave considerable protection, with isocitrate surpassing citrate, as in the succinoxidase experiments. In agreement with their effects on succinoxidase activity, malic acid was ineffective as a DPNH oxidase stabilizer at $18 \mathrm{~mm}$ and quite inhibitory at higher concentrations, as was malonate $(0 \cdot 136 \mathrm{M})$.

DPNH cytochrome $c$ reductase activity of homogenates aged at $0^{\circ}$ was also stabilized by the presence of succinate (not tabulated).

It had been previously reported (Eichel, 1956b) that dithionite-reduced DPN (final concentration $0.528 \mathrm{~mm}$ ) failed to stabilize the DPNH oxidase system of homogenates aged at $0^{\circ}$. It has now been found that homogenates aged with enzymically reduced DPN (final concentration $0.583 \mathrm{~mm}$ ) lose essentially no activity after $2-3 \mathrm{hr}$. and only $55 \%$ after a day.

The addition of succinate ( $18 \mathrm{~mm}$ ) to homogenate heated for $10 \mathrm{~min}$. at $30^{\circ}$ completely prevented the 
Table 10. Effect of ageing Tetrahymena pyriformis homogenates in the presence of sodium succinate on glutamic and $\beta$-hydroxybutyric dehydrogenase and fumarase activities

Enzyme activities were measured spectrophotometrically as described in the Experimental section. Portions (3 ml.) of fresh homogenate were incubated with $0.22 \mathrm{ml}$. of either water or $0.5 \mathrm{M}$-sodium succinate, and samples of these mixtures were assayed immediately and at the times indicated. The mixtures were stored at $0^{\circ}$ throughout.

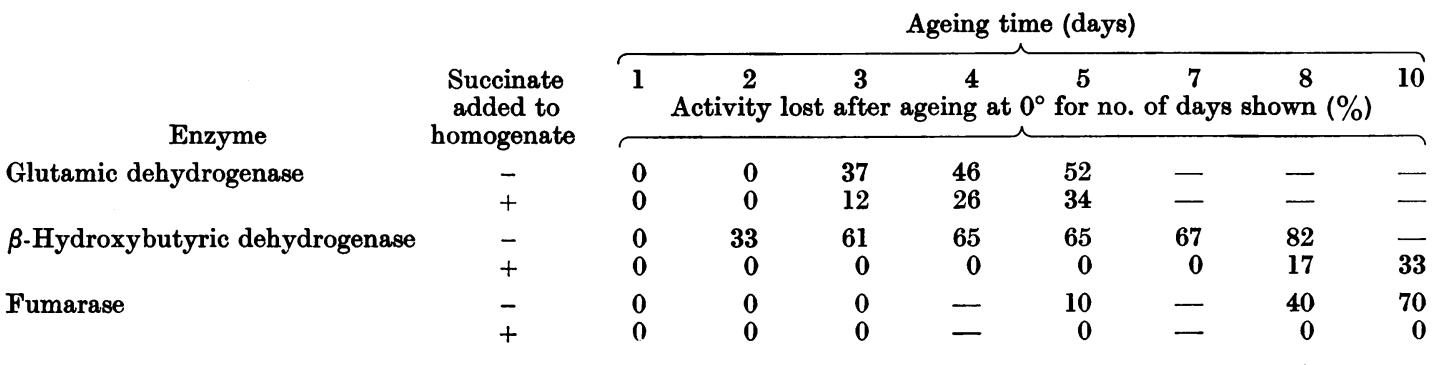

inactivation of DPNH oxidase activity, which amounted to $89 \%$ in homogenate heated without succinate.

\section{Glutamic and $\beta$-hydroxybutyric dehydrogenases and fumarase}

Glutamic dehydrogenase, measured by DPN reduction, was stable for 2 days and lost only $37 \%$ of the initial activity after 3 days, and $\beta$-hydroxybutyric dehydrogenase was slightly less stable.

Ageing of Tetrahymena homogenate at $0^{\circ}$ with succinate completely prevented the loss of $\beta$ hydroxybutyric dehydrogenase activity measured by DPN reduction for as long as 4-7 days (7 days for the preparation illustrated in Table 10). Glutamic dehydrogenase activity (DPN reduction) was also stabilized by succinate, but not quite as effectively.

Fumarase, a particulate enzyme (H. J. Eichel, unpublished results), proved to be extremely stable. In homogenates stored at $0^{\circ}$ and assayed at intervals, there was usually little loss of activity for 4-6 days, although in some preparations a 20-30\% decrease was observed after 3-4 days. To determine the effect of the stabilizing agents on the loss of fumarase activity, portions of homogenates were treated with succinate or lyophilized albumin extract or water. In homogenates whose activity had declined by $70 \%$ after 10 days, the presence of either succinate (Table 10) or albumin extract completely prevented the loss of activity. In a recent experiment, fumarase has been found to be stable for at least a month in the presence of either stabilizing agent.

\section{DISCUSSION}

The literature contains a number of instances of the stabilization or protection of enzymic activities by various techniques such as the use of inert proteins, coenzymes, metals, reducing agents, chelators or the specific substrates of the enzymes concerned. Keilin \& Hartree (1949) found that the impairment of heart succinoxidase activity which accompanied lyophilizing or repeated freezing at low temperatures could be restored by the addition of proteins or gelatinous phosphates to the test system. They ascribed the reactivation to the reestablishment of a suitable colloidal configuration in which the various components were so orientated that an enhanced mutual accessibility ensued. Similarly, Borei (1950) observed that in aged preparations of horse heart, cytochrome oxidase activity decreased on storage and could be reactivated through the addition of denatured globin or horse serum to the test system. Dialysis of the serum did not prevent the reactivation. Desiccation of the horse-heart preparations also lowered the initial cytochrome oxidase activity by $50 \%$, but if the desiccation was carried out in the presence of horse serum, the original activity was retained and the stability toward ageing was greater. Sacktor (1954) reported that in the absence of an inactive protein degenerative changes of housefly mitochondria began immediately after their isolation and lysis was complete within $30 \mathrm{~min}$. The addition of crystalline bovine serum albumin to a phosphorylating system of fly mitochondria prevented the complete abolition of phosphate uptake and the partial inhibition of oxygen uptake. Watanabe \& Williams (1953) found that crystalline albumin maintained the normal form and structure of insect sarcosomes for $24 \mathrm{hr}$. or longer. Crystalline serum albumin was also used by Polis \& Shmukler $(1957)$ to reactivate phosphorylation in aged $\left(0^{\circ}\right)$ rat-liver mitochondria; dialysis of the albumin did not aiter the effect. Recently, Nason \& Lehman (1956) showed that vitamin $E$ activated both DPNH- and succinic-cytochrome $c$ reductase of rat skeletal muscle but not cytochrome $c$ oxidase. Vitamin E could be replaced by a lipid cofactor obtained from isooctane extracts of purified DPNH 
cytochrome c reductase or by a lipid bound to crystalline bovine serum albumin. Peptone was reported to activate and stabilize diluted ox erythrocyte carbonic anhydrase (Scott \& Mendive, 1941), but dialysis did not prevent these effects, and gelatin and casein were also good stabilizers of the enzyme.

The results presented here on the stabilization of a number of components of the electron-transport systems of $T$. pyriformis by a water-soluble, thermostable, diffusible material of blood serum apparently associated with the albumin fraction, or by succinate, citrate or isocitrate, appear to be different from the findings reviewed above as well as from many other observations on protection and stabilization of enzyme activities too numerous to mention here. In attempting to assess these results, it is helpful to reconsider some of the salient points that have been given. As the enzyme systems studied increased in complexity, they exhibited increased instability, but the loss of activity of each enzymic link could be prevented for varying periods by the same stabilizing agent(s). Whether the mode of action of these agents is by (1) replacement of a disintegrating substance whose function is to gear the components of the particulate electron-transport systems to each other, (2) prevention of this disintegration, or (3) maintenance of a particular range of osmotic and ionic conditions or by some other means, little can be said at this time. Some of these possibilities are being explored further.

There is no evidence at the moment to indicate that the stabilization by blood serum (or crude albumin), peptone or yeast is effected by its content of both succinate and citrate. In fact, it can be calculated that in the volume of serum required for stabilization of the succinoxidase system, the total amount (Albritton, 1952) of these acids is 25-50 times less than the succinate level, which confers complete protection for $24 \mathrm{hr}$. Although it is conceivable that a group of physiologically occurring compounds, more or less structurally related to succinate, citrate and isocitrate, is responsible for the action of serum, the demonstrated marked specificity of the effective acids militates against this view. It is also possible that the action of serum (peptone, yeast) is due to some type of succinate-containing compound whose effect can be imitated by larger amounts of pure succinate.

Finally, it should be emphasized that the description of the labile electron-transport systems in the $T$. pyriformis preparations studied here does not necessarily imply that this is an inherent property of the systems studied in all types of homogenates and extracts of the organism. However, we have found that cell-free preparations made by freeze-thawing or sonic disruption also yield very unstable respiratory-enzyme activities.

\section{SUMMARY}

1. Homogenates of Tetrahymena pyriformis aged at $0^{\circ}$, or heated at $30^{\circ}$, lose overall succinoxidase, glutamic oxidase and $\beta$-hydroxybutyric oxidase activities rapidly. When different electron or hydrogen acceptors (dyes, diphosphopyridine nucleotide) are used in place of oxygen, stability increases, but only relatively. Previously, several reduced diphosphopyridine nucleotide-oxidizing enzymes assayed with oxygen, cytochrome $c$ or a dye as electron acceptor were found to behave similarly.

2. Addition of a crude bovine blood-albumin preparation to fresh Tetrahymena homogenates which were then aged at $0^{\circ}$, or heated under mild conditions, stabilized the complete succinoxidase and reduced diphosphopyridine nucleotide oxidase systems, as well as succinic dehydrogenase and reduced diphosphopyridine nucleotide cytochrome $c$ reductase, for $24 \mathrm{hr}$. or more. Crystalline bovine serum albumin and other proteins were incapable of stabilizing these enzymes, whereas horse, rat, human and chick serum, proteose peptone and yeast extract all protected against the loss of succinoxidase activity. Attempts to reproduce the action of the crude albumin extract by ageing homogenates at $0^{\circ}$ with various compounds which have been implicated in electron-transport function or which occur in blood plasma were generally unsuccessful.

3. The slower decline of the succinoxidase activity of rat-liver homogenates aged at $0^{\circ}$ could also be partly prevented by ageing in the presence of the crude albumin preparation.

4. The stabilizing material of the crude albumin preparation was shown to be water-soluble, diffusible and resistant to boiling at neutral or acid pH for short periods. An unheated or boiled lyophilized diffusate of the crude albumin extract stabilized the succinoxidase system of Tetrahymena homogenates aged for $24 \mathrm{hr}$. at $0^{\circ}$. Dialysis of rat serum, yeast extract and proteose peptone also abolished their ability to stabilize the succinoxidase system.

5. Under the experimental conditions described, the loss of succinoxidase activity was largely irreversible; the activity present at a given time after the preparation of homogenates was a function of the time of addition of the albumin extract to the homogenates.

6. Addition of sodium succinate to homogenates of $T$. pyriformis aged at $0^{\circ}$ also prevented for at least $24 \mathrm{hr}$. the rapid loss of activity of the complete succinoxidase and reduced diphosphopyridine nucleotide oxidase systems. Moreover, the activities 
of reduced diphosphopyridine nucleotide cytochrome c reductase, diphosphopyridine nucleotidelinked glutamic and $\beta$-hydroxybutyric dehydrogenases and fumarase were also stabilized for varying periods by ageing homogenates at $0^{\circ}$ with succinate.

7. When succinate-supplemented homogenates were centrifuged and the resultant particulate preparations resuspended in water, the stabilization effect was not apparent unless additional succinate was added to the resuspended preparations.

8. Heat denaturation of succinoxidase, reduced diphosphopyridine nucleotide oxidase and succinic dehydrogenase activities was overcome by heating homogenates in the presence of succinate.

9. Of a large number of compounds, many of which are closely related to succinic acid structurally, only isocitrate and citrate (as well as succinylcholine and succinimide) gave appreciable protection of the succinoxidase and reduced diphosphopyridine nucleotide oxidase systems, indicating that the structural requirements of the succinatestabilization effect are very rigid.

10. It is suggested that the present findings are different from previous observations on the stabilization and protection of enzymic activities by various methods, and the results are discussed.

I wish to thank Mrs Leona T. Rem for her skilled technical assistance. This investigation was supported by a research grant [E-1424(C3)] from the National Institutes of Health, United States Public Health Service.

\section{REFERENCES}

Albritton, E. C. (1952). In Standard Values in Blood, p. 91. Philadelphia and London: W. B. Saunders Co. Ltd.

Borei, H. (1950). Biochem. J. 47, 227.

Eichel, H. J. (1954). J. biol. Chem. 206, 159.

Eichel, H. J. (1955). J. Protozool. (suppl.), 2, 13.

Eichel, H. J. (1956a). J. biol. Chem. 222, 121.

Eichel, H. J. (1956b). J. biol. Chem. 222, 137.

Eichel, H. J. (1956c). Biochim. biophys. Acta, 22, 571.

Keilin, D. \& Hartree, E. F. (1949). Biochem. J. 44, 205.

Morton, R. K. (1955). In Methods in Enzymology, vol. 1, p. 25. Ed. by Colowick, S. P. \& Kaplan, N. O. New York: Academic Press Inc.

Nason, A. \& Lehman, I. R. (1956). J. biol. Chem. 222, 511.

Polis, B. D. \& Shmukler, H. W. (1957). J. biol. Chem. 227, 419.

Racker, E. (1950). Biochim. biophys. Acta, 4, 211.

Sacktor, B. (1954). J. gen. Physiol. 37, 343.

Scott, D. A. \& Mendive, J. R. (1941). J. biol. Chem. 139, 661.

Singer, T. P., Kearney, E. B. \& Massey, V. (1956). In Enzymes, Units of Biological Structure and Function, p. 417. Ed. by Gaebler, O. H. New York: Academic Press Inc.

Watanabe, M. I. \& Williams, C. M. (1953). J.gen. Physiol. 37, 71.

\title{
The Absorption of Cystine and Cysteine from Rat Small Intestine
}

\author{
BY M. W. NEIL \\ Department of Biochemistry, London Hospital Medical College, Turner Street, Whitechapel, London, E. 1
}

(Received 21 March 1958)

\begin{abstract}
Although there have been many reports in recent years of experiments designed to study the rates and mechanisms of the absorption of amino acids from the small intestine, cystine and cysteine do not appear to have been included in the compounds studied. This is perhaps due in part to the relative insolubility of cystine, and the fact that one of the more elegant techniques at present being used for such studies involves the use of isolated everted sacs (Wilson \& Wiseman, 1954) of small intestine, which cannot be used for the study of the absorption of cysteine. This is because the oxidation of cysteine in oxygenated solution is rapid, and anaerobic conditions inhibit absorption processes involving 'active transfer' (Wilson \& Wiseman, 1954) in this preparation.

In the work reported here cystine absorption has been studied with both the everted-sac technique
\end{abstract}

and a lumen-perfusion technique in situ, whereas the absorption of cysteine has been studied with the latter only.

Hess (1949) has briefly reviewed earlier work in the absorption of cystine, which, however, had not been concerned with the elucidation of the nature of the absorptive process, but only with the overall rates of absorption after ingestion by animals of the DL- and L-isomers of the amino acid. In his own experiments, in which he fed rats by stomach tube with solutions of the sodium salts of cystine isomers and of L-cysteine, Hess (1949) found no significant differences between the rates of absorption of L-, D- or DL-cystine. mesoCystine was absorbed at a lower rate than the other isomers. L-Cysteine was absorbed more slowly than the L-, D- and DL-isomers of cystine. A preliminary report of the work described here was given by Neil (1957). 